\title{
Fatigue Behavior and Physical Characterization of Surface-modified Ti-6Al-4V ELI Alloy by Micro-Arc Oxidation
}

\author{
Fernanda Potomati*a*, Enrico José Giordani ${ }^{\mathrm{b}}$, Laís Tereza Duarte ${ }^{\mathrm{a}}$, \\ Nelson Guedes de Alcântara ${ }^{\mathrm{a}}$, Claudemiro Bolfarini ${ }^{\mathrm{a}}$ \\ ${ }^{\mathrm{a}}$ Department of Materials Engineering - DEMa, Federal University of São Carlos - UFSCar, \\ CEP 13565-905, São Carlos, SP, Brazil \\ ${ }^{\mathrm{b}}$ Center of Characterization and Development of Materials - CCDM, \\ Federal University of São Carlos - UFSCar, CEP 13565-905, São Carlos, SP, Brazil
}

Received: September 8, 2011; Revised: November 25, 2011

\begin{abstract}
Anodizing has proven an effective method for preparing bioactive titanium and has been the subject of many studies regarding the performance and biological characterization of the layers obtained. However, the fatigue behavior of titanium alloys, after undergoing this process is still poorly studied. This study aims to investigate the influence of MAO (Micro-Arc Oxidation) process on the fatigue properties of titanium alloy Ti-6Al-4V. Therefore axial fatigue tests were performed to obtain SxN curves, of specimens in polished and anodized (MAO processed, phosphate salt solution, potential of 290 V) conditions. Roughness measurements, SEM, Raman spectra and X-ray photoelectron spectroscopy (XPS) analyses were used to characterize the features of the modified surface. SEM was also used to analyze the fatigue fractures of the tested specimens. The MAO process, with the parameters used in this investigation, had no influence on the fatigue behavior of the Ti-6Al-4V alloy, when compared to specimens without surface modification.
\end{abstract}

Keywords: surface modification, anodic oxidation, fatigue, titanium alloy

\section{Introduction}

Anodized surfaces result in better bone response, with better biomechanical results, when compared to machined surfaces ${ }^{1}$. The anodization of titanium has proven an effective method for preparing bioactive titanium ${ }^{2,3}$, and it has been the subject of many studies concerning biological performance ${ }^{4-9}$, and the characterization of the layers obtained $^{10-14}$.

The chemical and structural properties of anodic oxides can be varied within a very wide range of possibilities, varying the process parameters such as anodic potential, electrolyte composition, temperature and current.

Among the various processes of electrochemical oxidation, micro-arc oxidation (MAO), also known as anodic oxidation or plasma spark electrolytic oxidation (PEO), has been the subject of several studies of surface modification of titanium and its alloys for biomedical use $\mathrm{e}^{8-9,11-15}$. It is an anodic oxidation technique for deposition of ceramic layers on the surface of metals such as $\mathrm{Al}, \mathrm{Ti}, \mathrm{Mg}, \mathrm{Ta}, \mathrm{Zn}$ and their alloys $^{3}$. The MAO process is typically characterized by the phenomenon of electrical discharge on the anode in aqueous solution. The discharge channels have temperatures above $10.000 \mathrm{~K}$ and a local pressure of several hundred bars ${ }^{3}$.

In the case of surface modified implants, subjected to high load applications, for example, hip and knee prostheses, the effect of surface modification on the fatigue

*e-mail: fepotomati@yahoo.com.br life becomes a concern which should be considered ${ }^{16}$. It has been demonstrated ${ }^{16-18}$ that the fatigue behavior of an implant material can be strongly influenced by the surface modification process employed. However, there are few publications on the fatigue behavior of titanium and its alloys, subjected to the MAO process ${ }^{15}$.

If, on the one hand, the studies and performance characterization of bioactive layers are constantly updated, on the other hand, engineering studies and evaluation of mechanical properties of biomaterials submitted to new variations of surface modification are lagging behind. Thus, this study aims to investigate the influence of the MAO process of surface modification on the fatigue properties of titanium alloy Ti-6Al-4 V.

\section{Materials and Methods}

\subsection{Material}

Cylindrical specimens, with parallel reduced section (4.0 mm diameter), were machined from Ti-6Al-4V ELI alloy rods (ASTM F136). All the specimens were polished using a $0.3 \mu \mathrm{m} \mathrm{SiO}_{2}$ suspension in the final step of polishing resulting in a $\mathrm{Ra}=0.025 \mu \mathrm{m}$. Chemical composition and mechanical properties are listed in Table 1. The microstructure, shown in Figure 1, was fully equiaxed grains. 


\subsection{Anodic oxidation}

Anodic oxides were grown on the surface of the Ti6Al-4V electrodes (some of the polished cylindrical fatigue specimens) by the MAO technique ${ }^{19}$ : application of a cell voltage of $290 \mathrm{~V}$ for 300 seconds, in a phosphate solution (35.81 g.L $\mathrm{L}^{-1} \mathrm{Na}_{2} \mathrm{HPO}_{4}+13.80$ g.L $\mathrm{L}^{-1} \mathrm{NaH}_{2} \mathrm{PO}_{4}$ ) of pH 5. A conventional two-electrode cell was used in all anodization experiments; all the solutions were kept at room temperature (ca. $25^{\circ} \mathrm{C}$ ) throughout the tests. A stainless steel was used as counter electrode. In the MAO technique, a high potential for electrical breakdown (which for this alloy, and in this electrolyte is approximately $130 \mathrm{~V}$ ) is applied to the Ti-6Al$4 \mathrm{~V}$ alloy in order to obtain porous oxides ${ }^{19}$.

\subsection{Surface characterization}

The surface of the specimens modified by the MAO process was observed by SEM. The equipment FEI Quanta 400 was used. The roughness measurements were performed in the longitudinal axis of the fatigue specimen, using the equipment Taylor Hobson - ultra PGI 1000; the measurements methodology followed the ISO 4287:1997. The roughness parameters chosen for this characterization were Ra (Roughness Average), Rp (Maximum Profile Peak Height), Rv (Maximum Profile Valley Depth), Rz (Average Maximum Height of the Profile) and Rt (Maximum Height of the Profile). The first parameter is quite found in the literature and the other ones are used, among other cases, on the characterization of surfaces subjected to cyclic loadings. The Raman measurements were carried out with a T-64000 Jobin-Yvon triple-monochromator coupled to a chargecoupled detector (CCD). The XPS analyses were performed in ultrahigh vacuum (low 10-7 Pa range) using a Kratos Analytical XSAM HS spectrometer. Non-monochromatic $\mathrm{Mg} \mathrm{K} \alpha(\mathrm{h} v=1253.6 \mathrm{eV})$ radiation was used as X-ray source, with an emission current of $5 \mathrm{~mA}$ at a voltage of $12 \mathrm{kV}$. An electron flood gun was used to reduce charge effects. The high-resolution spectra were obtained with analyzer pass energy of $20 \mathrm{eV}$. The Shirley background, mixed Gaussian/Lorentzian functions, and a least-squares routine were used for peak fitting. The binding energies refer to the adventitious hydrocarbon C 1 seconds level set at $284.8 \mathrm{eV}$.

\subsection{Fatigue tests}

The axial fatigue test was carried out using servo hydraulic equipment INSTRON - model 8872 . In order to build up the $\mathrm{SxN}$ curves, the fatigue tests were planned to use 4 or 5 loads level with at least 2 specimens at each load level using $\mathrm{R}=0.1$ (stress ratio) and $20 \mathrm{~Hz}$ test frequency at ambient air conditions. The run out chosen was 5 million cycles.

\section{Results}

\subsection{Surface characterization}

As shown in Figure 2 for the oxide film formed using the MAO technique at $290 \mathrm{~V}$ on Ti-6Al-4V, the oxide coating exhibits rough and porous surface formed by a dense and compact film composed by numerous micro-protrusions
Table 1. Chemical composition and mechanical properties of the investigated Ti-6Al-4V alloy.

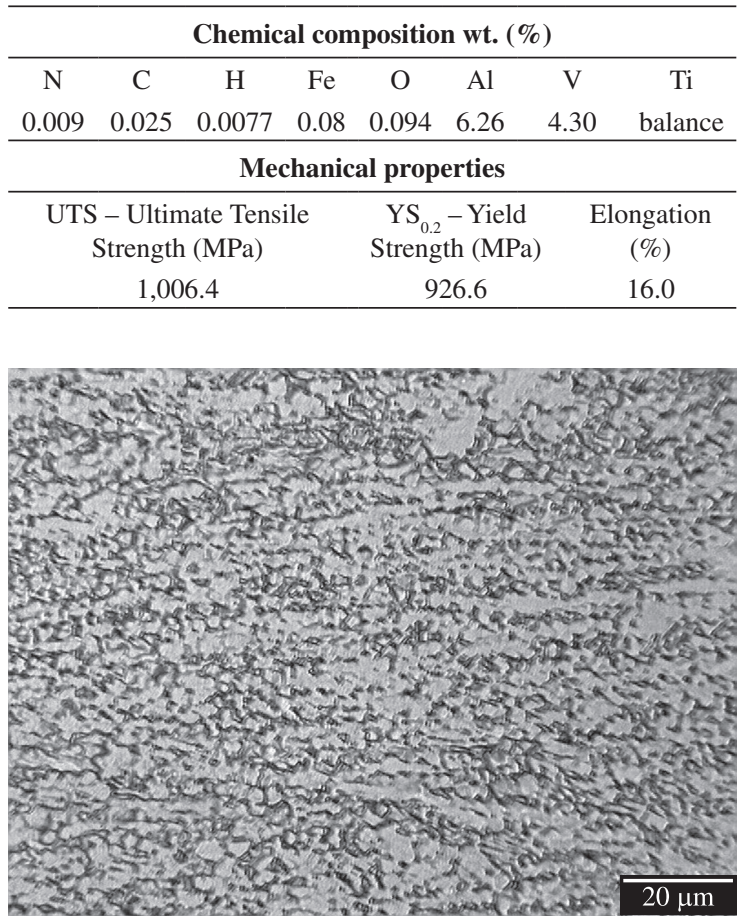

Figure 1. Microstructure of the investigated Ti-6Al-4V alloy. Fully equiaxed. Longitudinal view. Etch: Kroll.

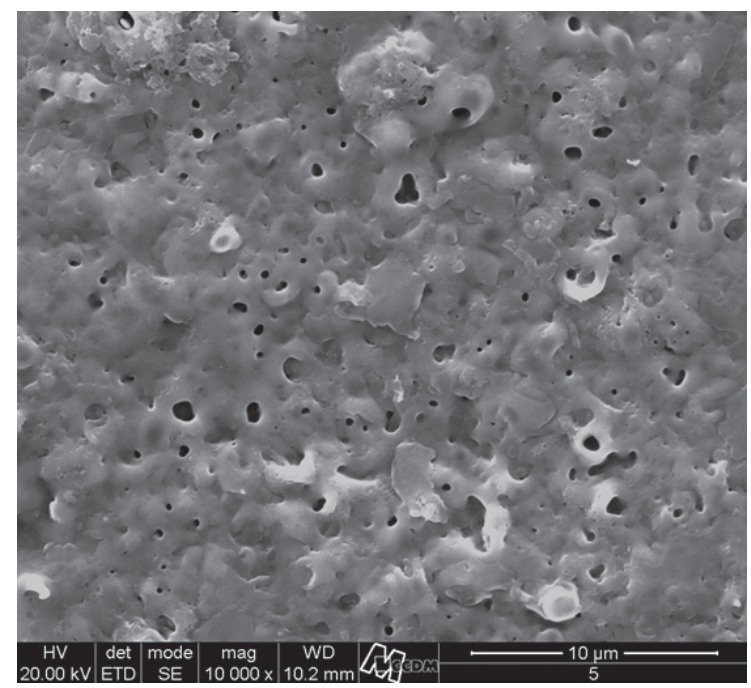

Figure 2. SEM image of the oxide film obtained by the MAO process.

with pores distributed randomly over the surface (diameter in the $1-3 \mu \mathrm{m}$ range).

Anodic oxides on $\mathrm{Ti}$ and its alloys grow at a rate of approximately $2 \mathrm{~nm} . \mathrm{V}^{-1[20]}$, which means that the thickness of the oxides formed under the designed conditions varies in the 500 to $600 \mathrm{~nm}$ range. It is known that the oxides growing under a MAO procedure do not exactly follow this anodization ratio due to several processes occurring at the very high voltage conditions ${ }^{19}$. However, as this deviation is 
observed only after the film-rupture voltage, the anodization rate remains a valid approach to estimate the oxide film thickness. It was possible to measure the oxide film thickness of the failed tested specimens using SEM analysis of the fracture surface and the oxide thickness was about $570 \mathrm{~nm}$.

The Raman spectra of the oxide growing on the Ti-6Al$4 \mathrm{~V}$ alloy (Figure 3) showed three bands in 150, 520 and $640 \mathrm{~cm}^{-1}$, which are characteristic of $\mathrm{TiO}_{2}$ in anatase phase.

About the XPS analyses, the Ti 2p spectrum (Figure 4) was fitted with only one component for each peak of the doublet, with Ti 2P3/2 459.1-459.3 eV, corresponding to $\mathrm{TiO}_{2}$, which was then determined to be the predominant surface oxide formed. Besides Ti, $\mathrm{O}$ and $\mathrm{C}$, small amounts of impurities (P, Ca and $\mathrm{Na}$ ) from the electrolyte were found.

Table 2 presents the results of the roughness of the polished specimen (reference) and the specimen modified by MAO process. Figure 5 shows the roughness profiles obtained.

\subsection{Fatigue and fractographic analysis}

The $\mathrm{SxN}$ curves obtained for the polished and anodized specimens are shown in Figure 6. The curves show that the fatigue strength in the polished condition was equal to that obtained for the anodized condition, which was $830 \mathrm{MPa}$.

The analysis of the fracture surface of specimens fractured in the fatigue test revealed commonalities among polished and anodized specimens. Table 3 summarizes these aspects.

All polished and anodized specimens presented the same fractographic features in all regions of the fracture. Figures 7 and 8 show the region adjacent to the nucleation site of one polished specimen and one anodized specimen, respectively.

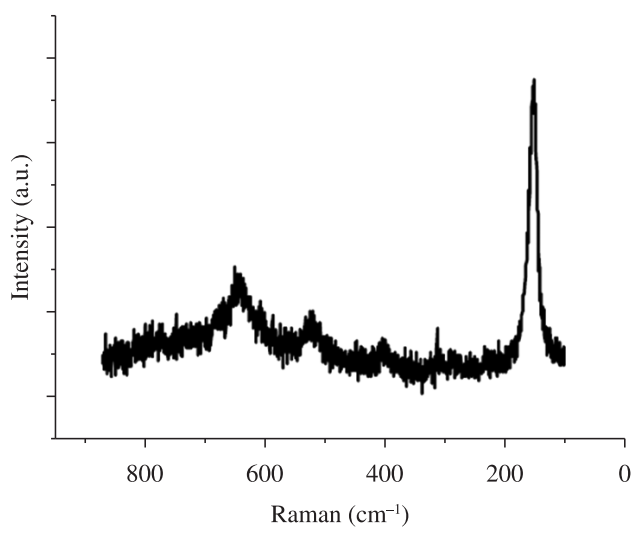

Figure 3. Raman spectra of the oxide growing on the Ti-6Al-4V alloy in a phosphate solution, $290 \mathrm{~V}$ and 300 seconds.

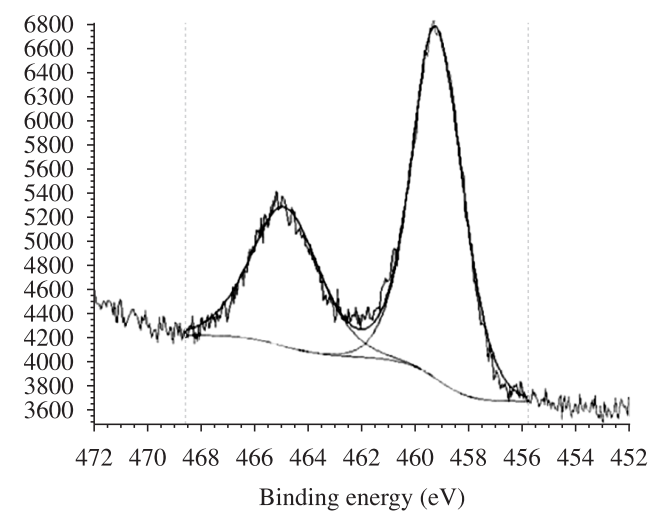

Figure 4. Ti $2 p$ spectra for Ti-6Al-4V alloy oxide films group up to $290 \mathrm{~V}$ for 300 seconds in phosphate solution.
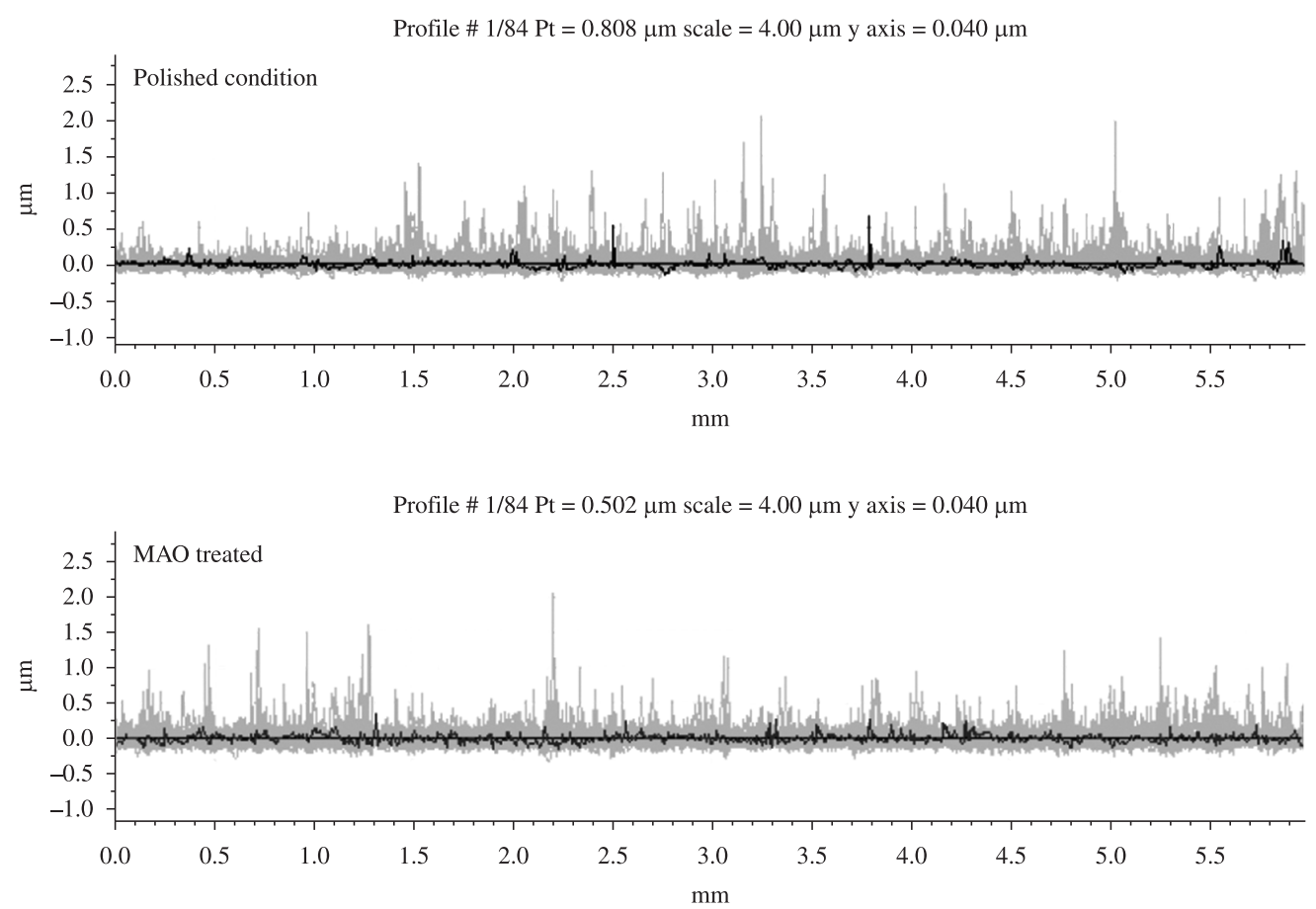

Figure 5. Roughness profiles of specimens in polished and MAO treated conditions. 
Table 2. Surface roughness results of the polished specimens (reference) and the specimens modified by MAO process.

\begin{tabular}{cccccc}
\hline & $\mathbf{R a}(\boldsymbol{\mu m})$ & $\mathbf{R t}(\boldsymbol{\mu m})$ & $\mathbf{R z}(\boldsymbol{\mu m})$ & $\mathbf{R p}(\boldsymbol{\mu m})$ & $\mathbf{R v}(\boldsymbol{\mu m})$ \\
\hline Polished & 0.026 & 0.572 & 0.291 & 0.218 & 0.073 \\
$\begin{array}{c}\text { Anodized } \\
\text { (MAO) }\end{array}$ & 0.041 & 0.678 & 0.371 & 0.250 & 0.121 \\
\hline
\end{tabular}

Table 3. Fractographic aspects of ruptured fatigue specimens with polished and anodized finishing.

\begin{tabular}{ccc}
\hline Aim of the observation & \multicolumn{2}{c}{$\begin{array}{c}\text { Description of the } \\
\text { features observed }\end{array}$} \\
\cline { 2 - 3 } & Polished & Anodized \\
\hline $\begin{array}{c}\text { Region adjacent to the } \\
\text { nucleation site }\end{array}$ & $\begin{array}{c}\text { Crack growth with } \\
\text { crystallographic } \\
\text { orientation. }\end{array}$ & $\begin{array}{c}\text { Same as } \\
\text { polished. }\end{array}$ \\
$\begin{array}{c}\text { Region away from the } \\
\text { nucleation site }\end{array}$ & $\begin{array}{c}\text { Fatigue striations. } \\
\text { Subsurface nucleation } \\
\text { site }\end{array}$ & $\begin{array}{c}\text { Two specimens } \\
\text { polished. }\end{array}$ \\
in 855 MPa. & $\begin{array}{c}\text { Same as polished. } \\
\text { One specimen in } \\
880 \text { MPa. }\end{array}$ \\
Multinucleation sites & Not present. & $\begin{array}{c}\text { One specimen in } \\
\text { the higher stress } \\
\text { (905 MPa) }\end{array}$ \\
Defect (notch) in the & Not present. & $\begin{array}{c}\text { Same as } \\
\text { polished. }\end{array}$ \\
\hline nucleation site. & & \\
\hline
\end{tabular}

The anodized layer can be observed in Figure 8. Comparing Figures 7 and 8 , it is evident that there is no difference in the appearance of the two fracture surfaces. Note that the fractures have a region of early crack growth with crystallographic orientation, typical of titanium and its alloys ${ }^{21}$. However, two of the polished specimens and one of the anodized specimens differed from the others, presenting subsurface nucleation. Figure 9 shows a subsurface nucleation of an anodized specimen. The two polished specimens had very similar subsurface nucleation appearance.

The top view of the fracture surfaces, and the crack initiation sites, were observed. In the case of anodized specimens, no previous damage, or any other peculiar characteristic that could be considered a preferable crack nucleating site, was observed, as shown in Figure 10.

\section{Discussion}

\subsection{Surface characterization}

In general, the anodic film morphology is critically dependent on the oxide growth behavior, especially during the micro-arc anodization. In fact, before the voltage oscillations begin, the specimens are already passivated by an oxide film that is basically a non-porous, compact, and uniform barrier-type film ${ }^{22,23}$. The plasma discharges on the samples are observed to become more intense during the MAO treatment as the current density is increased. When a micro-arc discharge extinguishes in the discharge channel, it is possible that coarse pores with large diameters remain on the coating surface. Indeed, the features observed in

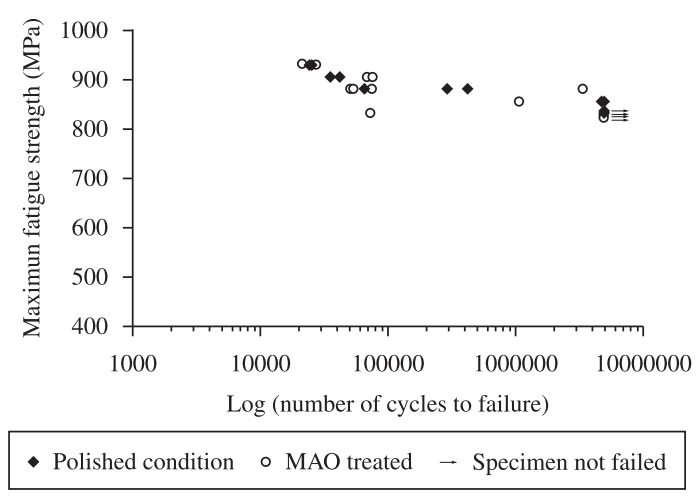

Figure 6. SxN curves of the Ti-6Al-4V alloy polished and modified by $\mathrm{MAO}$ process, $\mathrm{R}=0.1$.

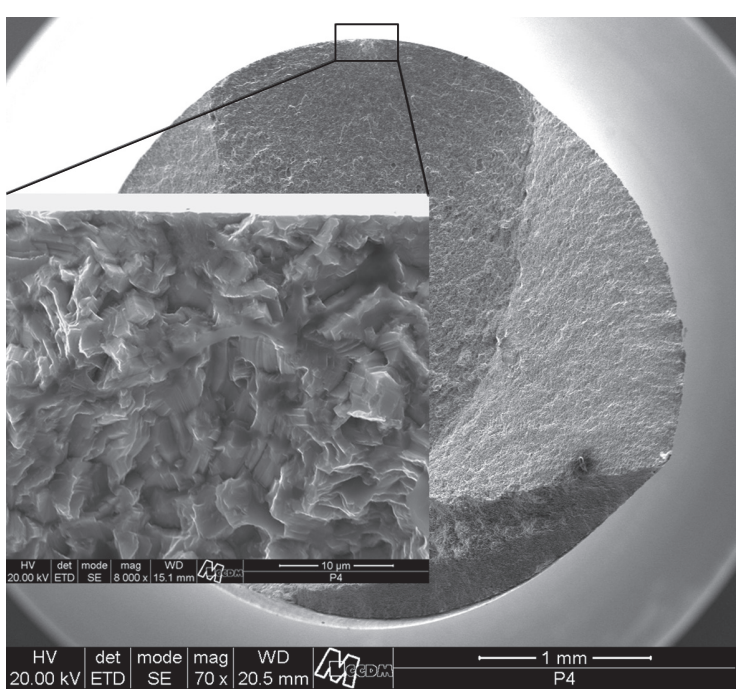

Figure 7. Fracture surface of a polished specimen ruptured during fatigue test: In detail: fracture surface adjacent to the crack nucleation point.

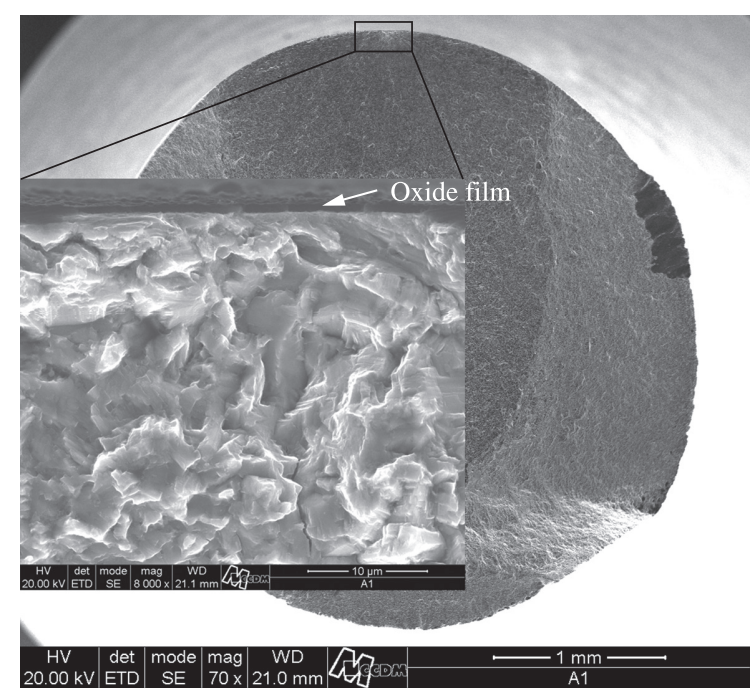

Figure 8. Fracture surface of a MAO processed specimen ruptured during fatigue test: In detail: fracture surface adjacent to the crack nucleation point. 


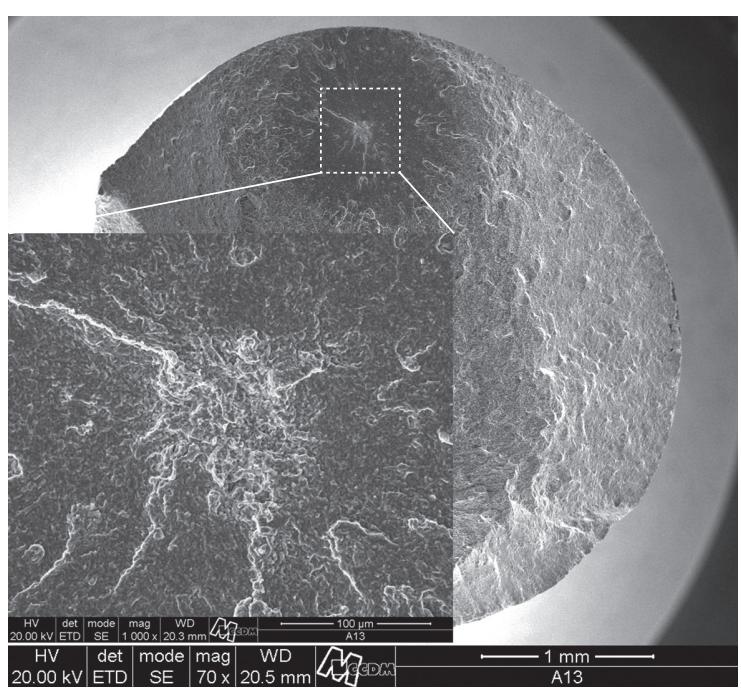

Figure 9. Subsurface nucleation of a fatigue crack in a MAO processed specimen, ruptured during fatigue test.

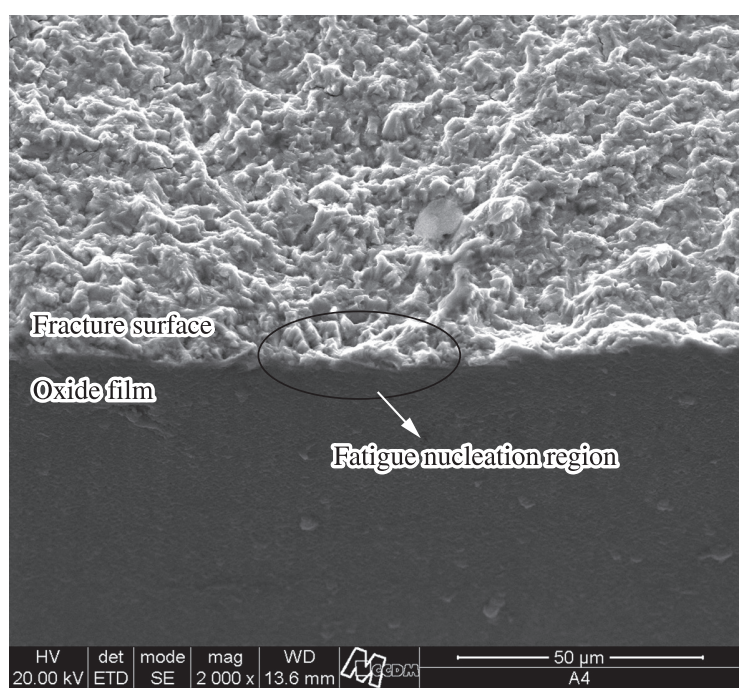

Figure 10. Nucleation site of the crack seen from the modified surface of a MAO processed specimen.

Figure 2 are due to the dielectric breakdown (particularly in the micro-arcing region) of the anodic film that occurs during the oxide formation.

The oxide most frequently found (grown naturally or by oxidation) on the pure titanium or its alloys is $\mathrm{TiO}_{2}$, which in turn can be found in three different phases: anatase, rutile and brookite. In Raman spectroscopy, five bands are characteristic of $\mathrm{TiO}_{2}$ anatase phase: 639, 513, 399, 197 and $144 \mathrm{~cm}^{-1}$. In the case of rutile bands features are: 610,446 , 236 and $142 \mathrm{~cm}^{-124]}$. In biomedical research, it has been reported that the formation of anatase phase on $\mathrm{Ti}$ and its alloys implants improves their bone compatibility ${ }^{[2,26]}$. The parameters used in this investigation were enough to obtain $\mathrm{TiO}_{2}$ in anatase phase (Figure 3).

Variations in the anodizing parameters seek to obtain a three-dimensional oxide and porous layer of rutile and / or anatase phases. These crystalline phases, with these characteristics have proven effective in inducing apatite formation on its surface. Surfaces containing calcium and phosphorus induce more easily the formation of new bone tissue, making the surface bioactive ${ }^{3}$. The result of the XPS analysis showed that, besides $\mathrm{Ti}, \mathrm{O}$ and $\mathrm{C}$, small amounts of impurities ( $\mathrm{P}, \mathrm{Ca}$ and $\mathrm{Na}$ ) from the electrolyte were found.

Industrial polishing usually presents $\mathrm{Ra}$ around 0.4-0.2 $\mu \mathrm{m}$. Polishing by hand, with better care, reaches a range of $\mathrm{Ra}=0.1-0.025 \mu \mathrm{m}$. In this study, the variation of the parameter Ra was $0.026 \mu \mathrm{m}$ for the polished to $0.041 \mu \mathrm{m}$ for the anodized. Both results are within the same category of surface finish (hand polishing 0.1-0.025 $\mu \mathrm{m}$ ). Thus, it can be stated that the variation obtained is small and that the anodizing followed the topographic features of the substrate. In terms of fatigue, the parameters $\mathrm{Rv}, \mathrm{Rp}, \mathrm{Rz}$ can be understood as a measure of the "notch" caused on the surface. The results in Table 2 show that the difference between polished and anodized is $0.1 \mu \mathrm{m}$, which confirms that the anodizing follows the profile of the substrate. In addition, Table 2 and Figure 5 indicate that the values Rp, $\mathrm{Rv}$ and $\mathrm{Rz}$ are low, which means that the MAO process, even though the result is a porous layer, did not show a pronounced notch effect.

\subsection{Fatigue and fractographic analysis}

The fatigue strength limit (830 MPa) and the shape of the curves (Figure 6) are similar for both polished and anodized conditions. Leinenbach et al. ${ }^{17}$, working with the Ti-6Al-7Nb with fatigue at $\mathrm{R}=-1$ in Ringer's saline solution, also had little significant difference between polished and anodized, about 550 and $530 \mathrm{MPa}$, respectively, in stress amplitude.

Other studies of fatigue of anodized specimens indicate that layers with micro-scale thickness ${ }^{27}$ decreased significantly in fatigue property, while for layers with nanoscale thickness ${ }^{17}$, the decrease is insignificant.

The similarity between the fatigue behavior of polished and anodized specimens is an indication that the difference in roughness between polished $(\mathrm{Ra}=0.026 \mu \mathrm{m})$ and anodized $(\mathrm{Ra}=0.041 \mu \mathrm{m})$ samples was not significant on fatigue life under the tests conditions carried out here. Besides, the subsurface fatigue crack nucleation observed in two polished specimens was also present in one anodized specimen (Figure 9). This evidence show that the anodic oxidation did not modify the substrate topography, as well as the characteristics (thickness and pore size) of the oxide film grown, also had no influence in the fatigue behavior of the Ti-6Al-4V.

In some cases, hydroxyapatite coating ${ }^{28}$ and some oxide coating ${ }^{27}$ with thickness about some tens of microns and with cracks inside the coatings can damage fatigue properties, since the cracks inside the coatings can induce the fatigue crack nucleation on the surface of the substrate. This behavior was not observed in the oxide film obtained in this study.

The SEM analysis of the initiation region of the fatigue crack of the anodized specimens (Figure 10) did not reveal any stress concentrator, this is also evidence that the anodizing process did not add any notch to the surface of the specimen. The roughness profiles indicate the same. 
The subsurface fatigue crack nucleation observed for both specimen (polished and anodized) in this study is common to the Ti-6Al-4V alloy when treated by shot peening ${ }^{29}$, which is a surface treatment that induces compressive residual stresses in the treated surface. Leinenbach et al. ${ }^{17}$ measured compressive residual stress of $406 \mathrm{MPa}$ in polished specimens $(\mathrm{Ra}=0.03 \mu \mathrm{m})$. Besides, polishing can contribute to increase fatigue properties because of the decrease of roughness surface ${ }^{30}$. Thus, the subsurface fatigue crack nucleation can be a result of the low roughness and compressive residual stresses, both from the polishing step.

Therefore, the high value of the fatigue strength of both specimens (close to $90 \%$ of the yield strength) can also be explained by the low roughness and by the possible presence of compressive residual stresses. Costa et al. ${ }^{31}$ studied Ti-6Al-4V aeronautical alloy, with polished finishing $(\mathrm{Ra}=0.46 \mu \mathrm{m})$. In their study, with $\mathrm{R}=0.1$, the fatigue strength was $900 \mathrm{MPa}$, even higher than the result obtained in this study.

\section{References}

1. Le Guéhennec L, Soueidan A, Layrolle P and Amouriq Y. Surface treatments of titanium dental implants for rapid osseointegration. Dental Materials. 2007; 23:844-854. PMid:16904738.

2. Yang B, Uchida M, Kim H-M, Zhang X and Kokubo T. Preparation of bioactive titanium metal via anodic oxidation treatment. Biomaterials. 2004; 25:1003-1010. http://dx.doi. org/10.1016/S0142-9612(03)00626-4

3. Liu X, Chu PK and Ding C. Surface modification of titanium, titanium alloys, and related materials for biomedical applications. Materials Science and Engineering R. 2004; 47:49-121. http:// dx.doi.org/10.1016/j.mser.2004.11.001

4. De Oliveira PT and Nanci A. Nanotexturing of titanium-based surfaces upregulates expression of bone sialoprotein and osteopontin by cultured osteogenic cells. Biomaterials. 2004; 25:403-413. http://dx.doi.org/10.1016/ S0142-9612(03)00539-8

5. Krupa D, Baszkiewicz J, Sobczak JW, Biliński A, Barczc A and Rajche B. Influence of anodic oxidation on the bioactivity and corrosion resistance of phosphorus-ion implanted titanium. Vacuum. 2003; 70:109-113. http://dx.doi.org/10.1016/S0042207X(02)00628-0

6. Setzer B, Bächle M, Metzger MC and Kohal RJ. The gene-expression and phenotypic response of hFOB 1.19 osteoblasts to surface-modified titanium and zirconia. Biomaterial. 2009; 30:979-990. PMid:19027946. http://dx.doi. org/10.1016/j.biomaterials.2008.10.054

7. Vanzillotta S, Sader MS, Bastos IN and Soares GA. Improvement of in vitro titanium bioactivity by three different surface treatments. Dental Materials. 2006; 22:275282. PMid:16054681. http://dx.doi.org/10.1016/j. dental.2005.03.012

8. Cheng S, Wei D, Zhou Y and Guo H. Preparation, cell response and apatite-forming ability of microarc oxidized coatings containing $\mathrm{Si}, \mathrm{Ca}$ and $\mathrm{Na}$ on titanium. Ceramics International. 2011;37:2505-2512. http://dx.doi.org/10.1016/j. ceramint.2011.05.077

\section{Conclusions}

The surface modification by MAO process of Ti-6Al$4 \mathrm{~V}$ alloy for biomedical purpose using the parameters employed in this study, did not modify the fatigue behavior of the material, which presented a fatigue strength value of $830 \mathrm{MPa}$, the same obtained for the reference specimens, with polished finishing.

The slight increase in the roughness promoted by the MAO process, when compared to polished specimen, was not significant in terms of the fatigue properties.

The features (thickness and porous size) of the oxide film did not influence in the nucleation of the fatigue cracks of the anodized specimens.

\section{Acknowledgements}

The authors are grateful to CAPES for the financial support to purchase raw materials. The authors would also like to thank Prof. Dr. Álvaro José Damião for the roughness measurements made in laboratories IEAv/CTA.

9. Gao Y, Gao B, Wang R, Wu J, Zhang L. J, Hao YL et al. Improved biological performance of low modulus Ti-24Nb4Zr-7.9Sn implants due to surface modification by anodic oxidation. Applied Surface Science. 2009; 255(9):5009-5015. http://dx.doi.org/10.1016/j.apsusc.2008.12.054

10. Souza GB, Lima GG, Kuromoto NK, Soares P, Lepienski $\mathrm{CM}$, Foerster $\mathrm{CE}$ et al. Tribo-mechanical characterization of rough, porous and bioactive Ti anodic layers. Journal of the Mechanical Behavior of Biomedical Materials. 2011; 4(5):796808. PMid:21565727. http://dx.doi.org/10.1016/j. jmbbm.2010.09.012

11. Cui X, Kim H-M, KawashitaM, Wang L, Xiong T, Kokubo T et al. Preparation of bioactive titania films on titanium metal via anodic oxidation. Dental Materials. 2009; 25(1):8086. PMid:18599115. http://dx.doi.org/10.1016/j. dental.2008.04.012

12. Song HJ, Park SH, Jeong SH and Park YJ. Surface characteristics and bioactivity of oxide films formed by anodic spark oxidation on titanium in different electrolytes. Journal of Materials Processing Technology. 2009; 209(2):864-870. http://dx.doi. org/10.1016/j.jmatprotec.2008.02.055

13. Kuromoto NK, Simão RA and Soares GA. Titanium oxide films produced on commercially pure titanium by anodic oxidation with different voltages. Materials Caracterization. 2007; 58(2):114-121. http://dx.doi. org/10.1016/j.matchar.2006.03.020

14. Krupa D, Baszkiewicz J, Kozubowski JA, Mizera J, Barcz A, Sobczak JW et al. Corrosion resistance and bioactivity of titanium after surface treatment by three different methods: ion implantation, alkaline treatment and anodic oxidation. Analytical and Bioanalytical Chemistry. 2005; 381(3):617625. PMid:15723257. http://dx.doi.org/10.1007/s00216-0042983-5

15. Apachitei I, Lonyuk B, F-Apachitei LE, Zhou J and Duszczyk J. Fatigue response of porous coated titanium biomedical alloys. Scripta Materialia. 2009; 61(2):113-116. http://dx.doi. org/10.1016/j.scriptamat.2009.03.017 
16. Niinomi M. Fatigue characteristics of metallic biomaterials. International Journal of Fatigue. 2007; 29(6):992-1000. http:// dx.doi.org/10.1016/j.ijfatigue.2006.09.021

17. Leinenbach $\mathrm{C}$ and Eifler D. Fatigue and cyclic deformation behaviour of surface-modified titanium alloys in simulated physiological media. Biomaterials. 2006; 27(8):12001208. PMid:16140373. http://dx.doi.org/10.1016/j. biomaterials.2005.08.012

18. Long $M$ and Rack HJ. Titanium alloys in total joint replacement - a materials science perspective. Biomaterials. 1998; 19(18):1621-1639. http://dx.doi. org/10.1016/S0142-9612(97)00146-4

19. Yerokhin AL, Nie X, Leyland A, Matthews A and Dowey SJ. Plasma electrolysis for surface engineering. Surface and Coatings Technology. 1999; 122(2-3):73-93. http://dx.doi. org/10.1016/S0257-8972(99)00441-7

20. Marino CEB, Nascente PAP, Biaggio SR, Rocha-Filho RC and Bocchi N. XPS characterization of anodic titanium oxide films grown in phosphate buffer solutions. Thin Solid Films. 2004; 468(1-2):109-112. http://dx.doi.org/10.1016/j. tsf.2004.05.006

21. Flugge J. The appearance of cracks and fractures in metallic materials. Dusseldorf: Verlag Stahleisen GmbH; 1997. p. 103-110.

22. Marino CEB, Oliveira EM, Rocha-Filho RC and Biaggio SR. On the stability of thin-anodic-oxide films of titanium in acid phosphoric media. Corrosion Science. 2001; 43(8):1465-76. http://dx.doi.org/10.1016/S0010-938X(00)00162-1

23. Macdonald DD, Biaggio SR and Song H. Steady-State Passive Films. Journal of the Electrochemical Society. 1992; 139(1):170177. http://dx.doi.org/10.1149/1.2069165
24. Oh C, Yoon S, Kim E, Han J, Chung H and Jeong H-J. Non-destructive determination of $\mathrm{TiO} 2$ concentration in cream formulation using Raman spectroscopy. Journal of Pharmaceutical and Biomedical Analysis. 2010; (53):762-766. PMid:20538420. http://dx.doi.org/10.1016/j.jpba.2010.05.008

25. Okazumi T, Ueda K, Tajima K, Umetsu N and Narushima T. Anatase formation on titanium by two-step thermal oxidation. Journal of Materials Science. 2011; (46):2998-3005. http:// dx.doi.org/10.1007/s10853-010-5177-x

26. Zhao Z, Chen X, Chen A, Huo G and Li H. Preparation of K2Ti6O13/TiO2 bio-ceramic on titanium substrate by microarc oxidation. Journal of Materials Science. 2009; (44):6310 6316. http://dx.doi.org/10.1007/s10853-009-3869-x

27. Apachitei I, Lonyuk B, F-Apachitei LE, Zhou J and Duszczyk J. Fatigue response of porous coated titanium biomedical alloys. Scripta Materialia. 2009; (61):113-116. http://dx.doi. org/10.1016/j.scriptamat.2009.03.017

28. Lynn AK and Duquesnay DL. Hydroxyapatite-coated Ti6Al-4V: Part 1: the effect of coating thickness on mechanical fatigue behaviour. Biomaterials. 2002; 23:1937-1946. http:// dx.doi.org/10.1016/S0142-9612(01)00321-0

29. Lutjering G and Williams JC. Engineering Materials and Processes - Titanium. New York: Springer; 2007. p. 116-120.

30. Wagner L and Bigoney JK. Fatigue of Titanium Alloys. In: Leyens C and Peters M. Titanium and Titanium Alloys Fundamentals and Applications. Weinheim: Wiley-VCH GmbH \& Co. KGaA; 2005. p. 153-185.

31. Costa MYP, Venditti MLR, Voorwald HJC, Cioffi MOH, Cruz TG. Effect of WC- $10 \% \mathrm{Co}-4 \% \mathrm{Cr}$ coating on the Ti-6Al-4V alloy fatigue strength. Materials Science and Engineering: A. 2009; (507):29-36. http://dx.doi.org/10.1016/j. msea.2008.11.068 